\title{
The Role Of Industry In The Economic Development Of Uzbekistan: Historical Analysis
}

\author{
Azizbek Alisher ugli Mamajanov \\ Teacher At The Department "Theory Of Civil Society" Of Andizhan State University, Andizhan \\ Region, Republic Of Uzbekistan
}

Journal Website: http://usajournalshub.c om/index,php/tajssei

Copyright: Original content from this work may be used under the terms of the creative commons attributes 4.0 licence.

\section{ABSTRACT}

The article reflects the process of industrial modernization in the Republic of Uzbekistan, sectoral reforms and their results, products produced by industrial enterprises and their current value, the number of employees and workers, the development of industrial production, archival sources, periodicals and statistics analyzed on the basis of data.

\section{KEYWORDS}

Industry, modernization, enterprise, manufacturing, national economy, diversified industry, economy.

\section{INTRODUCTION}

Nowadays, the developing country of Uzbekistan has become a supplier of raw cotton during the 70 years of Soviet colonialism. The transformation of the country into a region of agricultural production has led to the unilateral development of industrial production. The Communist Party's colonial policy, which was invisible in the administration but was an artificial obstacle to industrial development in the country, led the country to become an agrarian state based on cotton. The unilateral development of the country's economy has led to the country's low ranking among the countries of the Commonwealth of Independent States. This required a number of reforms to develop the economy of 
independent Uzbekistan. Consequently, during the transition period, the state became the main reformer, as a result of consistent reforms in governance, the country abandoned the planned economy and became a multi-sectoral development force based on free market relations.

\section{METHODS}

In the first 2 years of independence, the number of industrial enterprises and industries amounted to $11,025,000$, the number of employees and workers engaged in production reached 1,040,186, and their products amounted to $2,755,91337$ soums at wholesale prices by sector $[1, p .1]$. At the same time, in 1992, $24.4 \%$ of industrial enterprises and fixed assets of industrial enterprises in the country were provided with buildings, $16.8 \%$ with facilities, $12.3 \%$ of enterprises were provided with transmission equipment and $39.5 \%$ with machinery and equipment.

\section{RESULTS AND DISCUSSIONS}

As a result of the adoption by the Government of the Republic of Uzbekistan of the necessary by-laws regulating market relations, in 1994 alone, $300 \mathrm{mln}$. More than 1 billion soums went to the state treasury. During the first 9 months of this year, 1,300 newly established joint ventures produced goods worth more than 830 million soums [2, p.1].

By 1995, a diversified industry was established in the country, and the number of industries exceeded 100. The share of national cadres in the working class has increased. First of all, the industry of the republic appeared and developed on the basis of the needs and requirements of the main sectors of the national economy - cotton, silk, fruit, astrakhan. As a result, cotton growing, which has become the basis of the national economy, has become a leading industry. Of particular importance was the modernization and diversification of key industries of the republic. The transformation of industrial sectors in Uzbekistan in accordance with market requirements has given impetus to the integrated development of this industry.

Consequently, as a result of the implementation of measures aimed at the gradual modernization of industrial sectors, the stability of the economy is being strengthened, economic growth is developing and the competitiveness of the national economy is increasing. The implementation of structural reforms in the economy, strengthening the material and technical base of enterprises and the introduction of modern technologies, integrated development of enterprises, improving the investment climate, support for competitive production, laid the foundation for the development of industrial production.

As a result of the gradual development of the share of industry in production, the number of industrial enterprises in 1997 reached 10.2 thousand, their products at current prices amounted to 607.8 billion soums, and the growth rate of industrial production compared to 1996 was $104.1 \%$. did. By 2001, the number of industrial enterprises was 13.2 thousand, their products in current prices amounted to 2830.8 billion soums, and the growth rate of industrial production was $107.6 \%$ compared to 2000 , while in 2007 the number of industrial enterprises was 16.0 The products produced by these manufacturers amounted to 18447.6 billion. The growth rate of industrial production was $112.1 \%$ compared to 2006 [3, p.214]. 
A number of practical measures have been taken to ensure the rapid growth of the country's economy. Including,

- Large-scale, systematic and consistent implementation of market reforms;

- Strengthening measures to attract foreign investment;

- Modernization and renewal of production through profound structural changes in the economy;

- Establishment of new import-substituting and export-oriented industrial and manufacturing enterprises;

- Implementation of a well-thought-out policy aimed at the accelerated development of small business and entrepreneurship.

As a result, the conditions for Uzbekistan's accession to the world economy and opportunities for foreign economic activity began to emerge. In this situation, it was necessary to form a specific system of foreign economic relations, to develop a number of measures to establish foreign relations, to identify ways for our country to join the world economic system. Therefore, in order to raise the development of industry in the Republic of Uzbekistan to a new level, our government has adopted a number of decisions and laws. In particular, on the program of modernization and technical re-equipment of enterprises of the textile industry in 2006-2008 [4] On the program of modernization, technical and technological re-equipment of enterprises of the chemical industry for 2007-2011 [5], Cabinet of Ministers of the Republic of Uzbekistan On Amendments and Addenda to the Resolution of the Cabinet of Ministers of the Republic of Uzbekistan No. 4 of January 11, 2006 Resolution of the Government of the Republic of Uzbekistan dated July 1, 2008 No 146 “On measures to improve the organization and increase the responsibility of heads of local government and economic management for the implementation of the parameters of its development" [6], modernization of enterprises of the automotive industry in 20082009 Resolutions on the program of technical and technological re-equipment [7] served as a legal basis for the modernization of the country's industry.

As a result of reforms in the sector, by 2008 the country's GDP amounted to 38969.8 billion soums. The share of industry reached $23.5 \%$. These industrial enterprises employ $1,486.7$ thousand people and employ more than 9,148 billion people soums worth of products were produced [8, p.11].

The volume of industrial products (works, services) is large. The number of small auxiliary industrial enterprises (production of industrial products in non-industrial organizations) has been growing year by year, and their output in 2012 amounted to 51,059.3 billion soums. The growth rate of industrial production compared to 2011 increased by $107.9 \%$. The level of profitability (gross profit from sales of products, the percentage of losses relative to the cost of goods sold) was $35.9 \%$. These figures increased in 2013, the volume of industrial output amounted to 64354.7 billion soums, and the rate of return was 32.9\% [9, p.14].

In 2014, the GDP of the Republic of Uzbekistan amounted to 145846.4 billion soums. The gross value added of the industrial sector amounted to 34981.6 billion soums. soums, ie industrial production accounted for $24.0 \%$ of the country's GDP. During the same period, investments in fixed assets amounted to 35,233.3 billion soums, including 13164.5 bln. soums in industry or 37.4 percent. This year, the volume of products produced by industrial 
enterprises amounted to 75194.2 billion soums. soums. The growth rate of industrial production compared to 2013 amounted to 108.3\%. In particular, the extractive industry accounted for $97.7 \%$ and the processing industry for $110.7 \%$ [10, p.14-15].

As a result, the volume of industrial output in 2016 amounted to 111869.4 billion. soums. The growth rate of industrial production compared to 2015 amounted to $106.2 \%$. In particular, mining and quarrying accounted for $101.0 \%$, manufacturing $106.4 \%$, electricity, gas, steam and air conditioning $109.8 \%$ [11, p.14]. As a result of the accelerated implementation of structural change programs in various sectors of the economy, industrial production has developed. Raising the development of this sector to the level of government has been an important impetus for the development of the sector in practice.

In particular, the adoption of the Action Strategy for the five priority areas of further development of the Republic of Uzbekistan for 2017-2021, the third direction of this strategy is aimed at maintaining macroeconomic stability in the country through the development of economic reforms. In particular, in ensuring macroeconomic stability, the priority was given to "deepening structural changes, increasing its competitiveness through modernization and diversification of key sectors of the national economy". The country's economy, in particular, focuses on the formation of an investment climate for reform and modernization of leading industries, technical and technological renewal brought.

\section{CONCLUSION}

It creates opportunities for further development of the republic's industry through the modernization of industrial production. In addition, for more sustainable development of the industry, it is necessary to do the following:

- Development and implementation of advanced local technologies;

- Improving the quality and competitiveness of products through the introduction of modern information and communication technologies;

- Localization of production of finished products, components and materials;

- Elimination of shortcomings that hinder the level of localization;

- Reduction of imports of necessary goods, including equipment, which hinder the creation of new jobs;

- Comprehensive support and encouragement of production activities of small business and private entrepreneurship.

\section{REFERENCES}

1. National Archive of Uzbekistan, Fund M.110, List 1, Volume 90, Page 1.

2. The future of business economy // Khalk suzi, December 20, 1994. №247 (995) Page 1.

3. Annual statistical collection of the State Statistics Committee of the Republic of Uzbekistan 2008. -Tashkent 2009. Page 214.

4. http://lex.uz/docs/1083468 Collection of Legislation of the Republic of Uzbekistan, 2006, No. 46-47, Article 454; 2007, No. 23, Article 232; 2016, No. 51, Article 584

5. http://lex.uz/docs/1235169 Collection of Legislation of the Republic of Uzbekistan, 2007, No. 31-32, Article 316; 2009, No. 42, Article 449

6. http://lex.uz/search/nat?searchtitle=\%D1\%81 \%Do\%B0\%Do\%BD\%Do\%BE\%Do\%Bo\%D1\%82

Collection of Legislation of the Republic of Uzbekistan, 2008, No. 33, Article 318 
7. http://lex.uz/docs/1278530 Collection of Legislation of the Republic of Uzbekistan, 2007, No. 48-49, Article 484

8. State Statistics Committee of the Republic of Uzbekistan. Industry of Uzbekistan 2010. Statistical collection Tashkent 2010. Page 11

9. State Statistics Committee of the Republic of Uzbekistan. Industry of Uzbekistan. Statistical package Tashkent 2014. Page 14

10. State Statistics Committee of the Republic of Uzbekistan. Industry of Uzbekistan 2016. Statistical collection Tashkent 2016. Pages 14-15.

11. State Statistics Committee of the Republic of Uzbekistan. Industry of Uzbekistan 20142017. Statistical collection Tashkent 2018. Page 14. 